\title{
STATE AIDS, STATE MONOPOLIES, AND PUBLIC ENTERPRISES IN THE COMMON MARKET
}

\author{
Pierre Mathijsen*
}

The provisions of the Treaty establishing the European Economic Community (EEC) can be divided into two categories which roughly correspond to the two instruments through which the Community must fulfill its task of promoting "throughout the Community" a harmonious development of economic activities, a continuous and balanced expansion, an increased stability, an accelerated raising of the standard of living and closer relations between its Member States." These instruments, provided for under Article 2, are (a) the establishment of a Common Market and (b) the progressive approximation of the economic policies of tho member states. Part Two of the EEC Treaty ("Bases of the Community") deals with the former and includes provisions relating to the customs union, the agricultural and transport policies, and the freedom of establishment and of movement of workers, services, and capital. Integration of economic policies is to be implemented through the application of the tax provisions, the approximation of legal, economic, and social policies, and related devices as provided in Part Three of the Treaty ("Policy of the Community"). The rules on competition apply to both categories.

The establishment of the Common' Market was by far the more simple task. The rules provided for under the EEC Treaty in this field are of a technical nature and rather well defined, and the activities of the European institutions required to implement them constitute lawmaking in the largest sense. It is in unifying the market that the Community achieved its most spectacular results. Fundamental to the success of the Community in this area is the direction in Article 9(I) of the EEC Treaty that

[t]he Community shall be based upon a customs union covering the exchange of all goods and comprising both the prohibition, as between Member States, of customs duties on importation and exportation and all charges with equivalent effect and the adoption of a common customs tariff in their relations with third countries.

Thus, the purpose of this customs union is the removal of all traditional obstacles to the free movement of goods, a freedom which, according to the Court of Justice, is the most important of all the freedoms provided for by the EEC Treaty.2

Elimination of existing obstacles to free trade would be valueless, however, if

- Director with the Commission of the European Communities. This paper reflects only the personal views of the author.

${ }^{I}$ Treaty Establishing the European Economic Community, March 25, x957, CCF Coms. Mkr. Rep. If 1-5449, 298 U.N.T.S. 14-94 [hereinafter cited as EEC Treaty, art. - ], art. 2. All direct quotations from the EEC Treaty are taken from 298 U.N.T.S.

:Commission of the EEC v. Luxembourg \& Belgium, 8 Recueil de la Jurisprudence de la Cour 
there were not adequate rules to prevent the creation of new and different on'es. It is to this latter end that Community competition policy is directed. The EEC Treaty confers upon "competition" the role of a hinge between the two categories of unification: the Common Market will not be able to operate properly without undistorted competition, and the goals of the various policies to be implemented by the member states will not be achieved if the existing distortions of competition are not eliminated.

The roles generally assigned to competition are the protection of the consumer and the furtherance of greater efficiency in the production process. Besides these traditional roles, competition in the EEC aims at preventing both private enterprise and governments from introducing new trade barriers within the Common Market. The EEC Treaty provisions regarding competition contain two sets of rules applying on the one hand to undertakings (Articles 85 to $9 \mathrm{r}$ ) and on the other to the member states (Articles go and 92 to 94 ).

The rules governing undertakings have been sufficiently commented upon so that it may be presumed the reader has some familiarity with them. Articles 90 and 92-94, however, have received much less attention. This is surprising since it should be clear that certain governmental action's, such as state subsidies, can be much more disruptive of competition than any agreement between companies. The present article therefore will deal with the Community rules of competition which apply to member states.

\section{I}

\section{Co-ordination of State Aid Programs}

\section{A. The Legal Framework for Review of Aid Programs}

The EEC Treaty is only concerned with those actions of companies and governments which affect or can affect competition and trade between the member states. Indeed, whether interstate or intrastate trade and competition are affected determines the respective authority of the national and Community enforcement agencies, the latter having jurisdiction only when interstate trade is affected, as was clearly spelled out by the Court of Justice in I 666 in its decision in the Grundig-Consten case. $^{3}$ But even when duties, quotas, and other traditional obstacles to the free movement of goods have been abolished, interstate trade (or freedom of movement of goods) can be affected by several activities of public authorities. The EEC Treaty specifically mentions "discrimination based on nationality," "State monopolies of a commercial character," "public enterprises and enterprises to which they

817, 826 (Cour de Justice de la Communauté européenne) [hereinafter cited as Recueil de la Cour], [Court Decisions I96I-I966 Transfer Binder] OCH Comm. MKT. ReP. I 8004, at 7I70 (I962).

- Establissements Consten \& Grundig-Verkaufs-GmbH v. Commission of the EEC, r2 Recueil de la Cour 429, 495, [Court Decisions 196I-I966 Transfer Binder] CCH CoMm. MkT. REP. I 8046, at 7652 (I966).

EEEC Treaty, art. 7.

5 EEC Treaty, art. $37(\mathrm{r})$. 
[Member States] grant special or exclusive rights,"] "aid granted by a Member State or granted by means of State resources," and "internal charges of any kind." Most distortions caused by the latter can only be eliminated through harmonization of the legislation concerning turnover taxes, excise duties, and other forms of indirect taxation. State monopolies are being adjusted or eliminated altogether, and public undertakings constitute a specific problem which can' only be resolved through longterm policies. State aids, however, present the Community with problems of such frequency and magnitude that immediate solutions must be found.

\section{The Basis for Affirmative Control}

Article 92 of the Treaty refers to "any aid ... favouring certain enterprises or certain productions." A distinction is made between "aids" and general economic measures which, although also favoring undertakings or the production of certain goods, apply to all companies within a given country without regard to their location or the in'dustrial branch to which they belong. The latter include such things as tax measures, interest rates, and the levels of salaries and prices. These general measures, which can cause "general distortions," do not constitute "aids" within the meaning of the EEC Treaty, since they do not favor "certain" undertakings or the production of "certain" goods. The same applies to state measures aiming at improving the social, industrial, economic, or cultural infrastructure of a given area.

Article 92 also provides that any aid "which distorts or threatens to distort competition ... shall, to the extent that it adversely affects trade between Member States, be incompatible with the Common Market." Most aids, of course, do distort competition and affect interstate trade. If the main principle on which the Common Market is based is free movement of goods, a corollary is that all producers must operate, within this market, under similar conditions-they must compete on the basis of their own capabilities and at their own risks. Any measure, such as a subsidy, which artificially increases these capabilities or reduces the risks improves the competitive position of the interested company and thereby distorts competition and trade: the beneficiary either will be able to produce at a lower cost than would have been the case without the subsidy or will be able to maintain production which otherwise might have disappeared. It is for this reason that state aids are "incompatible with the Common Market." This incompatibility, however, is not absolute. The draftsmen of the EEC Treaty showed wisdom and realism when they provided for exceptions to the basic principle, as they also did in the case of Article 85. There first is a series of de jure exceptions: "aid of a social character," "aid intended to remedy damage caused by natural calamities," and "aid granted to the economy of certain regions of the Federal Republic of Germany affected by the

${ }^{8}$ EEC Treaty, art. 9o(I).

7 EEC Treaty, art. 92(I).

${ }^{8}$ EEC Treaty, art. 95.

- EEC Treaty, art. 92(I). 
division of Germany."10 But much more important is the second group of exceptions dealing with aids which "may be deemed [by the Commission'] to be compatible with the Common Market."11

Since it is the Commission which must decide whether the aids of this second group are compatible, the Treaty provides that it "shall be informed, in due time to enable it to submit its comments, of any plans to institute or to modify aids."12 Thus, member states must submit to the Commission drafts of proposals for all the aid systems which they intend to implement. The Commission then examines the proposals and, if need be, submits its comments. As will be seen below, the examination by the Commission mainly concerns the questions of whether the granting of subsidies is justified from a regional or industrial point of view and whether, in comparison with what other member states are doing in similar conditions, it is justified from a Community point of view.

If the Commission concludes that the aid-scheme is not compatible with the Common Market, it must initiate without delay a full inquiry into the case. The consequence of this step is that the member state concerned may not put its proposed measures into effect until this procedure has resulted in a final decision. ${ }^{13}$ The full inquiry consists of giving notice to the parties con'cerned to submit their comments. Generally, before reaching its decision, the Commission will initiate discussion both with the member state concerned and also multilaterally with all the member states.

\section{Exceptions in the Treaty}

On what grounds may the Commission decide that certain aids, which in principle are incompatible with the Common Market, may nevertheless be considered compatible? Article 92(3) provides for four exceptions.

(a) Underdeveloped Areas. State aids may be justified if they promote the economic development of areas where the standard of living is abnormally low or where there is serious underemployment. The Treaty thus provides two objective criteria, although it is left to the Commission to decide when a stan'dard of living is to be considered "abnormally low" or when underemployment is "serious." It is clear, however, that a comparison with the situation in other areas of the same country does not suffice and that in order to qualify for state aids, the underemployment of a given region must be considered serious in' terms of the total Community. Member states tend to overlook this essential element and to view their internal problems from a purely national point of view. In this field, therefore, a major task of the Commission is to add a "Community dimension" to the solutions entvisaged by the member states.

\footnotetext{
${ }^{10}$ EEC Treaty, art. $92(2)$.

${ }^{11}$ EEC Treaty, art. $92(3)$.

${ }^{12}$ EEC Treaty, art. 93(3).

${ }^{18} \mathrm{ld}$.
} 
Once the Commission has concluded that the above conditions are fulfilled, it may consider the proposed aids as compatible with the Common Market even when the repercussion on competition and interstate trade might harm the interests of industries in other member states. Since the effective functioning of the Common Market requires "a harmonious development of economic activities" throughout the Community, ${ }^{14}$ it is the responsibility of the Community as a whole to contribute to the recovery of the "un'derdeveloped" areas. Within the Community of the Six, the south of Italy (Mezzogionno) and the west and southwest of France constitute such areas. With the recent expansion to the Community, there is no doubt that large parts of Ireland, Norway, and Denmark will also have to be included in this category, as will some areas in Northern Ireland, Scotland an'd Wales.

The Treaty also provides a possible exception to the general principle of incompatibility for "the development of . . . certain economic regions, provided that such aids do not change trading conditions to such a degree as would be contrary to the common interest."15 Thus, a distinction had to be established between these "economic regions" and the "regions where the standard of living is abnormally low or where there exists serious underemployment." This was done by dividing the Community of the Six into "central areas" and "peripheral areas," as is discussed below.

(b) Common Interests and Serious Disturbances. The second exception provided for by Article 92(3) concerns aid "to promote the execution of important projects of common European interest or to remedy a serious disturbance in the economy of a Member State." A concrete example of an important European project can be found in a proposal recently submitted by the Commission to the Council concerning measures of industrial policy aimed at developing the European aeronautical industry. In an accompanying notice, the Commission declares that it will favorably consider aids proposed by member states for joint projects. With respect to the concern for serious disturbances, the Commission has admitted, as compatible with the Common Market, temporary aids proposed by the Italian Government to help the companies suffering from economic recession. It is clear that such aids must be strictly limited in time since the disturbance referred to in' this provision of Article 92 is neither a long-term problem of regional underdevelopment nor a question of reconversion in specific areas or industries.

(c) Regional and Sectoral Aids. The third group of exceptions to the principle of non-compatibility is probably the most important one. It has been applied in a great number of cases and covers both regional and industrial problems. The particular concern under this exception is aids intended to assist the development of certain parts of the territory of a member state (regional aids) or certain industries (sectoral aids). ${ }^{16}$ While the aids admissible under the first exception above are

\footnotetext{
${ }^{16}$ EEC Treaty, art. 2.

${ }^{25}$ EEC Treaty, art. $92(3)$.

${ }^{16} I d$.
} 
intended for underdeveloped areas, those dealt with in the present category are to be applied in regions presenting particular problems of a social and economic nature. In most cases, these problems result from the presence of declining traditional industries such as coal, steel, textile, and shipbuilding. They are not, as is the case in underdeveloped areas, caused by a lack of infrastructure or industrialization or trained labor. Thus, the solution to the problems in this third area is to be found in' modernization, reorganization, and diversification. If the necessary measures are initiated in time, such industrial restructuring can be carried out with success in a period which is relatively short compared to the time needed to bring some sort of economic structure to a backward region.

In deciding whether or not such measures are acceptable under Article 92, the Commission must be satisfied that they do not "change trading conditions to such a degree as would be contrary to the common interest." Herein lies the difference between the aids destined to develop backward regions and the aids needed to restructure other areas: the latter will not be considered compatible by the Commission if it is feared that the harm to industries in other member states resulting from such aids goes beyond an acceptable limit. In this domain the Commission enjoys farreaching powers.

The same criterion is applied to sectoral aids-those aids which are aimed at restructuring a given branch of an industry which is no longer competitive. In such cases the Commission will also require the member state concerned to submit a comprehensive program for the industry which shows that modernization or rationalization will make likely not only the survival of the industry, but also its continued competitiveness. Thus, the Commission will not tolerate aids aimed at maintaining enterprises which have little chance for continued viability. Such a decision was taken recently in regard to certain Belgian aids. ${ }^{17}$

(d) New Categories of Aids. The last exception provided for by Article 92(3) "concerns "categories of aids as may be specified by decision of the Council acting by means of a qualified majority vote on a proposal of the Commission." Such a new category was defined by the Council in the case of aids to the production of ships. Normally aids to production cannot be considered compatible with the Common Market because it is impossible to evaluate them in advance. Recognizing that they might be necessary in some situations, the Council adopted a directive concerning production aids to shipbuilding in July, $1969 .{ }^{18}$

\section{B. The Impact of the Commission Upon Aid Programs}

\section{r. The Nature of the Commission's Task}

It should be apparent that major questions of policy confront the Commission when it is asked to pass judgment on "plans to institute or to modify aids."19 While

\footnotetext{
${ }^{17}$ Journal officiel des Comadunautés européennes, Jan., 1972, at Lio/22 [hereinafter cited as E.E.C. J.O. ].

${ }^{18}$ E.E.C. J.O., Aug. 15, 1969, at L206/25.

${ }^{19}$ EEC Treaty, art. 93(3).
} 
the Commission has always appreciated the delicacy of its task, the difficulties which the Commission has encountered have become increasingly complex as the Community has advanced toward its goal of economic unification. In the early years, the Commission dealt primarily with aid proposals which sought to improve conditions in truly underdeveloped areas. Proposals were made which affected predominantly agricultural areas such as the eastern border regions of Germany, the south of Italy, the southwest and west of France, and the northern' region of Holland. While the Commission decisions with respect to these areas were not easy ones, all of these cases involved areas which were rather geographically distant from each other and in which the level of economic development was rather low, while within the Community itself free movement of goods and services was still in its initial stage.

In the mid-196o's, a number of events combined to produce a dramatic change in the nature of the aids-decisions which the Commission was required to make. Among the most important of these events was the achievement of the customs union in 1968 , which produced a major shift in the interaction of member states. Also important was the decline of some major traditional industries situated in economically well-developed areas which together formed what might be regarded as a single economic region in the center of the Community.

The consequences of this new situation proved harmful for regional and industrial development and for the growth of free competition. Indeed, member states were faced with economic and social problems of a new nature and new magnitude; they felt compelled-socially and politically-to allocate massive aids in those regions which previously had constituted the very backbone of their industrial growth. The national authorities soon realized that only new investments, rather than reorganization of existing ones, could bring relief to the areas affected by the industrial decline. "Regional aids"-a term which is merely a more polite means of identifying financial contributions allocated to industrial and commercial undertakings-offered the prospect of improving the position of declining industries relative to competitors, which often were located a short distance away in another member state. Thus, all over Western Europe frantic efforts were begun to attract investors, mainly from abroad. In order to make investment attractive, all kinds of advantages were being offered, ranging from the straightforward financial grant or loan at reduced rates to the subtle fiscal measures including preferential treatment of the managers in regard to their personal in'ome tax. This situation gave rise to stiff "competition" among the various member states as each one tried to outdo his neighbor. Incentives became more numerous and more generous. To enable the state to adjust its aid scheme to the "needs" of each individual case, the proposals submitted for Commission opinion became less specific. Some proposals merely granted national authorities the necessary powers to "aid" new investors without specifying the form and amount of the aids or the location of the recipient industry or area.

This caused considerable difficulty for, as indicated above, aids can generally only be granted either to develop particular regions or to facilitate the development 
of particular economic activities. In order to be able to declare an aid compatible with the Common Market, the Commission must not only be informed of the precise areas where a state intends to grant aids, but also of the economic and social reasons justifying intervention in favor of these areas. Thus, the Commission must have at its disposal the most recent data pertaining to a geographically wide territory forming an "economic region." This data must include information on the region's unemployment and prospective employment, average income, trends in economic development, rate of emigration or commuting, and so on. It is only on the basis of such information that the Commission can possibly agree to the necessity of helping a given area. Once it has been accepted that aids are indispensable to further the economic development of a given region, the member state must also designate the areas within this region where aids will be granted and specify how much aid will be available. The latter is particularly important since the Commission is concerned about the spiraling increases in the amounts of financial assistance used by member states over the past years to attract new investments.

It is the task of the Commission, first, to estimate the actual value of all the advantages which can be granted to an investor and, second, to compare this amount to that which is being offered by national authorities in other areas. The major difficulties of implementing this double task are obvious. The generally accepted method for evaluating the amount of aid an investor is able to receive is to express the various advantages as a percentage of the investment, the latter consisting of the price to be paid for ground, building, and machinery. While such a calculation is reasonably simple where grants and loans are involved, it becomes entirely impossible where the incentive takes the form of tax holidays and other non-monetary aids to production.

\section{The Principles of Co-ordination}

Because of these difficulties, the Commission decided in 1969 that it could no longer fulfill its role with regard to evaluating regional development aids. The Commission indicated that it would require member states either to inform it of the most important individual cases in which aids would be granted or to modify their aid schemes in such a way as to enable the Commission to actually assess the benefit accruing to an enterprise. It was this latter method which was eventually chosen. In close co-operation with the member states, the Commission drafted the so-called "principles of co-ordination for aids destined to develop certain regions." These principles were the object of an official Notice of the Commission to the Council. ${ }^{20}$ In the Notice, the Commission invited the governments of the member states to bind themselves politically to the regional aid principles. This was done in the form of a Resolution of the representatives of the governments of the member states in Council.

The principles of co-ordination for regional aids consist of eight "rules" which

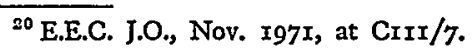


are designed to put an end to member states' overbidding each other and to allow the Commission to evaluate the social and economic consequences of the aid schemes of which it is notified pursuant to Article 93(3). They are as follows:

(a) There will be progressive implementation of the rules. First, the principles will be applied in the so-called "central areas" of the Community and not in the south of Italy, the southwest and west of France and the eastern border regions of Germany. Second, the application will take place gradually over a period of one year starting January $\mathrm{r}, \mathrm{x} 972$ (transitional period).

(b) The co-ordination of aids consists primarily of four aspects: a single ceiling for the amount of aid, transparency, regional specificity, and control of sectoral repercussions.

(c) The amount of a regional aid granted by a member state may not exceed twenty per cent of the net (after-tax) value of a given investment calculated in accordance with a method set out in the agreement on principles. Exceptions to this ceiling may be granted by the Commission.

(d) Transparency of the aids and the aid-schemes is considered essential for the application of the principles. Consequently, the member states will, during the transitional period, eliminate all non-transparent aids.

(e) Regional specificity is required. This means that (i) regional development aids may not be granted over the whole territory of a member state (except Luxembourg), (ii) the areas within which aids are available must be clearly defined, (iii) aids may not be given in geographically isolated areas which will not influence the development of a region, (iv) the amount of aid must vary with the nature, magnitude, and urgency of the socioeconomic problems to be solved, and (v) differences in the amount of aid available to the various areas must be clearly indicated.

(f) The absence of sectoral specificity constitutes an urgent problem for which a solution must be found, for the granting of regional development aids to companies in certain branches of industry might have harmful repercussions at the Community level.

(g) The Commission will supervise the implementation of the principles. To this end member states will notify the Commission of all significant cases in which aids are granted. A case is significant when the amount of aid is in excess of two million dollars.

(h) A committee of government officials will periodically examine the results of the application of the principles.

Article 154 of the Act attached to the Treaty of Accession signed at Brussels on January 22, 1972, provides that these principles "will be supplemented to take account of the new situation of the Community after accession." 21 This concerns mainly that part of the Notice and the Resolution which determines the central regions of the Community.

${ }^{21}$ Treaty concerning the Accesston of the Kingdom of DenMark, Ireland, the Kingdom of Norway and the UNITED Kingdom of Great Britain and Northern Ireland to the European Economic Commonity and the European Atomc Energy Community (with Final Act) and Decigion or the Council of the European Communities concerning the Accession of the said Strates to the European Conl and Steer Communtty, CmNd. No. 4862, at 58 (1972). 
At first sight these principles might not appear to be very revolutionary or even restrictive in regard to the right of the member states to grant regional development aids. In order to appreciate the significance of these principles, however, it must be remembered that under the EEC Treaty member states retain most of their powers with regard to industrial and regional aids. The task of the Community is to promote a harmonious development of economic activities throughout the whole Community ${ }^{22}$ and to institute a system insuring that competition in the Common Market is not distorted. ${ }^{23}$ The Community has not been empowered to initiate or even propose the granting of aids; its role is limited to promoting, facilitating, and supervising state-initiated programs. The Treaty does not even refer to the co-ordination of regional development aids, although it should be clear that such co-ordination is an essential part of both Community-wide economic development and achievement of a free competition system. When the representatives of the governments of the member states undertook in October, ro7r, to abide by the princioles drafted bv the Commission, it was the first time in the Community's history that an overall ${ }^{\text {. }}$ approach to the problems raised by state aid was initiated. It should be noted that the resolution of October, I97I, is termed a "first" resolution, indicating that the member states agree that further co-ordination is necessary.

\section{Common Regional and Industrial Policies}

The Commission has confronted directly the problems arising from the overbidding among member states for outside investments. By underscoring the external consequences of national aid schemes, the Commission has been able to move this initial problem area toward a solution. A second problem area which has required the attention of the Commission involves the absence of common regional and industrial policies.

It should be clear that the amount of public incentives made available by states must be related to the urgency and magnitude of the problems to be solved. The task of the Commission is to evaluate urgency and magnitude of particular problems, not on a national level, but from a Community perspective. To further this goal, a classification of the yarious regions within the Community according to social and economic criteria is necessary. Needless to say, such a classification not only requires detailed statistics taken in accord with a uniform method but also is, as a political matter, a most delicate, if not hazardous, task. A first approach has involved the division of the Community into two types of areas: the industrialized "central areas" and the lesser developed, mainly agricultural "peripheral areas." But within the two cateorgies further classifications are necessary. Unfortunately, no progress has been made in this regard, and the Commission, until now, has had to base its evaluations on the often fragmentary regional justifications which are made

\footnotetext{
${ }^{22}$ EEC Treaty, art. 2.

${ }^{28}$ EEC Treaty, art. $3(f)$.
} 
available on a case by case basis. As a result, it has encountered difficulty in insuring that aid decisions are made from a Community point of view.

A similar problem exists in regard to specific aids to industry-sectoral aidsintended "to facilitate the development of certain activities."24 Here again the absence of an overall industrial policy complicates the Commission's task. By granting these aids to one branch of an industry, member states seek to implement a national industrial policy aimed at developing so-called "advanced industrial technology" or restructuring declining industrial sectors. The need to co-ordinate national policies is obvious lest the solution of one country's difficulties create new and similar problems in some other member state. In this field, joint policies and joint decisions as to the priority to be given particular industrial sectors would greatly facilitate the Commission's work and thereby increase the efficiency of the national endeavors.

Some progress has been made. By advocating co-ordinated aids to the textile and shipbuilding industries, the Commission has clearly chosen in favor of two industrial sectors plagued by serious economic problems. Similarly, by laying down rules for subsidies to the computer and aeronautical industries, the Commission has indicated a priority as to which technologies should be actively developed. These beginnings must be extended to other sectors if development is to occur with appropriate regard for Community interests.

\section{II}

\section{State Monopolies: Preserving Competttion Within the Community}

State aids must be viewed not only in regard to their regional or industrial objectives, but also as potentially disruptive of fair competition within the Common Market insofar as they affect trade between' member states. As was said, trade is affected because the artificially-improved competitive position of a producer in a given member state will inevitably affect its direct competitors in other member states, particularly with regard to their exports to the subsidy-granting state. However, public incentives are not the only means by which governments can influence interstate trade-that is, control imports and exports-and thereby jeopardize the free movement of goods. State monopolies represent a similar interference.

State monopolies are defined as "any body by means of which a Member State shall de jure or de facto, either directly or indirectly control, direct or appreciably influence importation or exportation between Member States."25 Although economically much less relevant, these monopolies are much more effective than state aids in preventing the free flow of goods. Monopolies exist in three member states-France, Germany, and Italy-and cover a great variety of products ranging from flint and cigarette-paper to the more important manufactured tobacco and alcohol products. The origins of state monopolies vary widely. In some cases they were established

\footnotetext{
24 EEC Treaty, art. 92(3). 1

${ }^{95}$ EEC Treaty, art. $37(\mathrm{I})$.
} 
to insure the protection of public health (quinine in Italy), or the supply of vital products (salt in Italy), or the protection of public safety (explosives and gunpowder in France). In most cases, however, the reason for the creation of state monopolies is to be found in the desire of the state to reserve for itself the huge profits accruing from the sale of products such as cigarettes and alcohol. Whatever their basis, the monopolies, once created, were used to prevent imports from other member states.

Article $37(\mathrm{I})$ of the EEC Treaty now provides that "Member States shall progressively adjust any State monopolies of a commercial character in such a manner as will ensure the exclusion, at the date of the expiry of the transitional period, of all discrimination between the nationals of Members States" in regard to conditions of supply or marketing of goods. In its last paragraph this Article requires the Commission to "make recommendations as to the particulars and the timing according to which the adjustments referred to in this Article shall be carried out." ${ }^{26}$ Several such recommendations were sent by the Commission to the member states concerned during the transitional period which ended on December $3 \mathrm{r}, \mathrm{rg} 69$. In the last recommendations sent in November and December, r 969 , the Commission expressed its views as to the manner in which Article 27 should be interpreted and implemented. The Commission noted that Article 27 is part of the title of the EEC Treaty concerned with the free movement of goods and more particularly of the chapter dealing with the elimination of quantitative restrictions between the member states. In the Commission's view, Article 37 seeks to achieve, by the end of the transitional period, the same results for the products of a state monopoly of a commerical character as are obtained for other products through the application of Articles 30 to 34. That is, the free movement of such goods should be insured. ${ }^{27}$ This construction is extremely important, for it assimilates products which come under a national monopoly to all other products in regard to their free movement.

The Commission's recommendation's also concluded that the only difference between monopoly-products and others lies in the procedure employed to achieve their free movement. The desired freedom might not be achieved if a state monopoly were permitted to assert its exclusive import, export, and distribution rights as a basis for controlling the import of products from other member states. According to the Commission, Article 37 requires more than the elimination of discrimination's resulting directly from the national provisions applying to monopoly-products, for this result could otherwise be obtained through the application of treaty provisions prohibiting measures having the same effect as quantitative restrictions on imports. ${ }^{28}$ Article 37 aims also at excluding even the "possibility" of discrimination. Such a possibility could result from particular powers of the state monopolies concerning the import, export, or distribution of products. For these reasons, the Com-

\footnotetext{
${ }^{26}$ EEC Treaty, art. $37(6)$.

${ }^{27}$ See, e.g., E.E.C. J.O., Feb. 8, I97x, at $\mathrm{L}_{3} \mathrm{I} / 2$.

${ }^{28}$ EEC Treaty, arts. 30-33.
} 
mission concluded that the most effective solution would be an elimination of the exclusive rights of the state monopolies. Thus, although Article 37 only requires the member states to "adjust" their state monopolies, the Commission has expressed as its opinion that the best way to adjust is to "eliminate." In several cases member states have agreed to such elimination. These agreements affected salt, cigarettepaper, lighters, flint, bananas, matches, and tobacco-products in Italy and matches, gunpowder and explosives, potash and tobacco-products in France.

In regard to the new member states (Denmark, Ireland, Norway, and the United Kingdom) Article 44 of the Act attached to the Treaty of Accession provides that they "shall progressively adjust State monopolies of a commercial character within the meaning of Article $37(\mathrm{x})$ of the EEC Treaty, so as to ensure that by $3^{\mathrm{I}}$ December 1977 no discrimination regarding the conditions under which goods are procured and marketed exists between nationals of Member States. The original Member States shall have equivalent obligation in relation to the new Member States." ${ }^{29}$ The same article further provides that the Commission' shall make recommendations, beginning in 1973 , as to the time and manner in which the adjustment must be carried out.

It seems, therefore, that the obstacle to free movement of goods resulting from the existence of state monopolies and the ensuing distortions of competition will soon disappear.

\section{III}

\section{Public Enterprises in the Community}

In addition to state aids and state monopolies, state or public enterprises present a third means by which member states can influence interstate trade. The relative importance of these institutions varies widely among the member states. While in Italy nearly forty per cent of production is state-controlled, practically all industrial production in the Benelux countries and in Germany is in the hands of privatelyowned companies. But even in those countries where "public enterprises" play an important role, the influence of public authorities within these enterprises varies from outright ownership to minor participation in the capital of companies. What is important, however, is the amount of control public authorities can exercise within a given company. It is only in those cases in which they can dictate market behavior that states can be held responsible for violation of treaty provisions by these "public" companies.

It should be obvious that the existence of state control does not only depend upon the number of shares owned by a public authority. When an undertaking is whollyowned, there can be no doubt about the state's responsibility, a point which is not really disputed by any government. Even if it is claimed that the company operates as a fully independent and autonomous one, the fact that the state-or any other

${ }^{20}$ CMND. No. 4862 , at 23. 
public authority-is the sole owner puts it in a position of control with respect to the firm's market behavior, and the state can' be held responsible for any violation of the Treaty provisions committed by the company. The EEC Treaty, furthermore, is indifferent in regard to ownership of enterprises; whether a company is owned by the state or by private persons does not affect the implementation of the treaty provisions. Article 222 clearly states that " $[t]$ his Treaty shall in no way prejudice the system existing in Member States in respect of property."

A somewhat more difficult situation is presented when the state is not the sole owner of an enterprise. In these cases, the critical feature is the degree of control available to the state. According to Article 90, there is state control where, irrespective of the amount of capital owned by the state, member states have granted "special or exclusive rights" to public undertakings. In such cases the Treaty provides that "Member States shall ... n'either enact nor maintain in force any measure contrary to the rules contained in this Treaty, in particular, to those rules provided for in Article 7 and Articles 85 to 94 inclusive."30

A different situation exists when "[an] enterprise [is] charged with the management of services of general economic interest or [has] ... the character of a fiscal monopoly."31 Such undertakings "shall be subject to the rules contained in this Treaty, in particular to those governing competition, to the extent that the application of such rules does not obstruct the de jure or de facto fulfilment of the specific tasks entrusted to such enterprise." 32 But the Treaty adds that in no case may "the development of trade ... be affected to such a degree as would be contrary to the interests of the Community."33

With respect to this latter type of un'dertaking, it is clear that the draftsmen of the Treaty were preoccupied with "public enterprises" only because they realized that member states could use such enterprises to influence interstate trade. The classic example, of course, is the state-owned or controlled railway company which is told by the government to reserve its procurements for national companies, thereby closing the borders for exports from other member states. The draftsmen appreciated, however, that exceptions to the general.rule on' competition were unavoidable where, for example, "services of general economic interest" are involved. Here again the railway company which enjoys a monopoly situation in a given country provides a good illustration of the need for a realistic appraisal of the intended impact of competition rules: It is obvious that the rules of Article 86 regarding the "action by one or more enterprises to take improper advantage of a dominant position within the Common Market or within a substantial part" do not apply. A similar conclusion can be reached with respect to postal services; energy production and delivery, and the like. But these are exceptions which confirm the rule that all

\footnotetext{
${ }^{80}$ EEC Treaty, art. $90(\mathrm{r})$.

s2 EEC Treaty, art. 90(2).

sId.

"Id.
} 
enterprises in the Common Market, whatever their regime of ownership, are to implement the Treaty provisions.

When the Commission is of the opinion that the Treaty has been violated, the only difference between a private company and a state-controlled company is the manner in which adherence to the Treaty is achieved. In the case of a private company, the Commission will hold it responsible and may impose a fine if thero is a violation of Articles 85 or 86 . With respect to a state-controlled undertaking, the Commission will insure the application of the Treaty provisions either by starting proceedings against the member state concerned, in accordance with Article 169, or "where necessary, issue appropriate directives or decisions to Member States."34

\section{Conclusion}

When reference is made to the competition policy of the EEC, it is generally assumed that this means Articles 85 and 86 . These provisions prohibit all agreements between undertakings and all concerted practices which may affect trado between member states and which have as their object or effect the distortion of competition. They also proscribe any abuse of a dominant market position insofar as it may affect trade between member states. As is apparent from their wording, the raison d'être of these well-known provisions is to maintain free movement of goods within the Common Market and guarantee fair competition. These articles constitute the "rules applying to undertakings" as provided by section I of the Rules on Competition. 'The intent of the discussion' in this article is to familiarize the reader with another set of rules on competition which concern exclusively the member states. Until recently, these other provisions have attracted much less attention than those relating to undertakings, although the former are at least as important to the Community's achieving and maintaining the free movement of goods and fair competition. These rules touch upon essential elements of the overall economic policy of member states. While the interpretation and application of the rules concerning undertakings is, practically speaking, a purely legal matter, the implementation of Articles 37, 90, and 92-93 requires a political approach in most cases. This difference in the nature of these two sets of rules is also expressed in the wording of the various provisions: it is noteworthy that according to Articles 85 and 86 agreements and abuse of a dominant position are not only "incompatible with the common market," but also "prohibited," while state aids are only "incompatible." This distinction obviously follows from the essential difference in the nature of the actions referred to in the two sets of rules: Articles $85-86$ concern actions by economic entities with a profit-making motive, while Articles 90, 92, and 93 concern actions of public authorities motivated by their responsibility for the welfare of their peoples.

For the Commission, the implementation of the competition rules concerning

\footnotetext{
8t EEC Treaty, art. 90(3).
} 
member states, especially those covering state aids, requires, first, the examination and evaluation of the regional or industrial objectives of a proposed aid measure. The acceptability of these objectives is a major determinant of their compatibility with the Common Market. Secondly, the Commission must determine whether trade between member states is affected to an extent contrary to the common interest. When applying the rules of competition to member states, the Commission must, more than in other fields, weigh the national against the Community interest. In doing so, it assumes a significant responsibility in regard to the harmonious development of economic activities throughout the Community. 


\section{DUKE LAW JOURNAL}

A law review edited by students of Duke University School of Law and devoted to a discussion of legal topics of current interest. Subscription Rate: $\$ \mathrm{I} 2.00$ (six issues).

\section{VolUME I972 Nos. 5-6 InCLUdE:}

\section{LATTY SYMPOSIUM ON CORPORATE AND SECURITIES LAW}

The symposium includes a tribute to Dean Elvin R. Latty, eleven' authored articles, two book reviews, and student material centering on corporate and securities law.

VOLUME I973 No. I INCLUDES:

\section{ADMINISTRATIVE LAW SYMPOSIUM}

The $\mathrm{S} \& \mathrm{E}$ Contractors Case-Beheading the

Hydra or Wreaking Devestation? Robert S. Pasley

Ratemaking as Rulemaking-The New Approach at FPC:

Ad Hoc Rulemaking in the Ratemaking Process......Melvin G. Dakin

The Broadcast Licensee as Fiduciary: Toward the

Enforcement of Discretion.....................Jonathan Mallamud

An Agenda for Investigation: Should the APA

be Amended to Provide Standards for Agency

Review of Administrative Trials? William Fauver

FOURTH ANNUAL PROJECT

FEDERAL ADMINISTRATIVE LAW DEVELOPMENTS-I972

Address Subscription and Inquiries to the

Research \& Managing Editor

\section{DUKE LAW JOURNAL}

Duke University School of Law

Durham, North Carolina 27706 